Irmeli Palmberg är akademilektor i biologins och geografins didaktik samt docent i miljöpedagogik vid Åbo Akademi Vasa i Finland. Hon är projektledare bl.a. inom den nordiska baskunskapsforskningen.

Eila Jeronen är universitetslektor i biologins och geografins didaktik samt docent i pedagogik vid Uleåborgs universitet och Lapplands universitet i Finland.

Maria Svens är forskarstuderande vid Åbo Akademi Vasa i Finland och klasslärare vid Munknäs lågstadieskola i Helsingfors i Finland.

Eija Yli-Panula är lektor i biologins och geografins didaktik vid Åbo universitet, Finland.

John Andersson är lektor vid University College Sjælland, Danmark.

Gunnar Jonsson är universitetslektor vid Luleå tekniska universitet, Sverige.

IRMELI PALMBERG

Åbo Akademi Vasa, Finland

irmeli.palmberg@abo.fi

\section{EILA JERONEN}

Uleåborgs universitet, Finland

eila.jeronen@oulu.fi

\section{EIJA YLI-PANULA \\ Åbo universitet, Finland \\ eijyli@utu.fi}

JOHN ANDERSSON

University College Sjælland, Danmark joa@ucsj.dk

\title{
Blivande lärares (åk 1-6) baskunskaper i Danmark, Finland och Sverige - 1. Kunskaper och uppfattningar om människans biologi
}

\begin{abstract}
Alarming trends in science in Nordic schools, indicating a diminishing interest among students, a lack of knowledge and competence among teachers as well as a decreasing amount of science in teacher education sparked this study of student teachers in Denmark, Finland and Sweden. This quantitative and qualitative study of teacher students' views of human biology made it clear that human biology is seen as basic teacher knowledge by a majority of the students, in Finland in particular. The student teachers' level of knowledge in human biology is very low. They have difficulties in explaining basic body functions, for example in relation to the human blood circulation system. They lack understanding of how various body organs work together, a fact that makes teaching and pupil guidance more difficult. Nordic teacher education should provide more time for diagnosing and developing student teachers' critical and scientific thinking skills as well as problem-based science teaching.
\end{abstract}

\section{INLEDNING}

Enligt de internationella undersökningarna TIMSS (Trends in International Mathematics and Science Study) och PISA (Programme for International Student Assessment) är nordiska 15-åriga elevers naturvetenskapliga kunnande över eller nära OECD-ländernas medeltal. Finlands resultat i den senaste PISA-undersökningen från 2006 med betoning på naturvetenskaper var betydligt 
bättre än resultaten från något annat deltagande land (Arinen \& Karjalainen, 2007). Finland har dessutom visat en uppåtgående trend i alla PISA-mätningar åren 2000, 2003 och 2006, medan Sveriges trend i motsvarande undersökningar samt i TIMSS 1995, 2003 och 2007 visar en tydlig nedåtgående trend. Danmarks och Norges resultat visar ingen klar trend, men bägge ländernas resultat blev under OECD-ländernas medeltal i den senaste PISA-mätningen (Skolverket, 2009). När dessutom intresset för naturvetenskaperna i samma åldersgrupp i hela Norden har minskat (Et Fælles Løft, 2008; Sjøberg \& Schreiner, 2006), finns det anledning att undersöka orsakerna. En svensk analys av lärares uppfattningar om ämnesinnehåll visar på bristande kompetens och behörighet att undervisa i de naturorienterande ämnena hos lärare i de lägre årskurserna (Frändberg \& Bach, 2009). Samma gäller de elevcentrerade arbetsmetoderna. Lärare antar ofta att eleven själv kan upptäcka naturvetenskapliga samband och skriva hypoteser utan att ha fått någon teoretisk bakgrund eller hjälp från läraren (Andrée, 2007; Lundin, 2007). En utbildning med god kvalitet förutsätter att lärarna har tillräckliga kunskaper och färdigheter att utifrån målen för utbildningen planera och genomföra en meningsfull undervisning. För detta krävs såväl ämneskunskaper som didaktisk kompetens (SOU, 2007).

Andelen naturvetenskaplig undervisning inom lärarutbildningen för lärare med inriktning mot årskurserna 1-6, har under de senaste tio åren minskat i alla nordiska länder. I Danmark saknar hälften av de lärare som undervisar ämnet natur/teknik kompetens i naturvetenskapliga ämnen (Danmarks Lærerforening, 2010). De flesta lärare för årskurserna 1-6 (klasslärare) i Finland har endast de obligatoriska 2 ECTS av högskolebiologi i sin examen, medan läget i Sverige är ännu sämre. Där undervisas detta ämne av en stor andel lärare som saknar högskolestudier i NO-ämnen (naturvetenskapligt orienterade ämnen) (Frändberg \& Bach, 2009; Kärrqvist \& Frändberg, 2008). Forskningen visar att speciellt blivande lärare för årskurserna 1-6 i allt lägre grad har den kunskap och de färdigheter som behövs för att framgångsrikt kunna utöva sitt yrke (Abell, 2007; Palmberg, Jeronen \& Yli-Panula, 2008; Palmberg \& Svens, 2010; Rice, 2005). Missuppfattningar om naturvetenskapliga fenomen är allmänna och svåra att eliminera eftersom elever och lärare oftast inte är medvetna om dem (Abu-Hola, 2004; Andersson, 2008; Clément, 2003; Palmberg, 2008; Palmberg \& Svens, 2010).

Intresse för människans biologi finns i alla åldrar. Av de tillfrågade temaområdena i PISA 2006 var människans biologi det som mest intresserade OECD-ländernas elever. Totalt 68 $\%$ ansåg området vara intressant (Arinen \& Karjalainen, 2007). Flickor är i allmänhet mer intresserade än pojkar. Rädsla för sjukdomar, behovet att hjälpa andra, erfarenheter och upplevelser från biologilektioner och biologiläraren i skolan anses vara de viktigaste faktorerna som påverkar intresset (Finke, Klee \& Berck, 1998). Kunskap om egen anatomi och fysiologi upplevs som viktig även av blivande lärare (Palmberg \& Svens, 2010). Temaområdet anses vara viktigt och nyttigt för att kunna välja hälsosamma levnadsvanor, förstå näringens och motionens inverkan på fysisk och psykisk hälsa (Andersson, 2008), men också för att kunna göra miljömedvetna val som beaktar naturen och naturresurserna (Palmberg \& Svens, 2010).

Eftersom läraren har en central roll i utvecklandet av elevernas naturvetenskapliga begrepp och tänkande, är det viktigt att undersöka blivande lärares förkunskaper i och uppfattningar om människokroppen för att senast inom lärarutbildningen kunna bearbeta eventuella missuppfattningar och kunskapsbrister. Syftet med denna undersökning är att med hjälp av ett kvantitativt kunskapstest och kvalitativa intervjuer diagnostiskt kartlägga blivande lärares förståelsenivå beträffande människans biologi. Med baskunskap avser vi sådan kunskap som lärare behöver för att framgångsrikt kunna utöva läraryrket. Läraren behöver med andra ord ha en helhetskunskap och förståelse om människokroppens basfunktioner för att kunna hjälpa eleverna att nå de ämnesspecifika läroplansmålen i temat. Läraren ska inneha en betydligt högre kunskaps- och förståelsenivå än vad eleverna kommer att ha. Undersökningen är en separat del av ett större, pågående nordiskt projekt, där lärarstuderandes baskunskaper och naturvetenskapligt tänkande analyseras i syfte att utveckla lärarutbildningen i Norden. 


\section{Skillnader i skolsystem och lärarutbildning i Danmark, Finland och Sverige}

En grundskola (folkeskole) omfattar såväl förskolan som årskurserna 1-9 i Danmark, Finland och Sverige. De största skillnaderna mellan dessa länders skolsystem förekommer först i den gymnasiala utbildningen. Danmark har ett treårigt gymnasium, där utbildningen börjar med ett gemensamt grundförlopp som bl.a. inkluderar grunder i naturvetenskap (biologi, fysik, kemi, naturgeografi). Efter ett halvt års studier väljer eleverna ett av minst fyra erbjudna ämnesinriktade studiealternativ, varav ett är naturvetenskapligt (Undervisningsministeriet, 2008). Finland har ett nationellt, allmänbildande gymnasium, där grundstrukturen är enligt en nationell, övergripande läroplan (Grunderna för gymnasiets läroplan, GGL, 2003). Naturvetenskapliga ämnen ingår som såväl obligatoriska ämneskurser som valbara fördjupningskurser. Gymnasieskolan i Sverige består av nationella program, specialutformade program och individuella program. Det finns totalt 17 nationella gymnasieprogram. Dessa innefattar alltid åtta s.k. kärnämnen, varav ett är naturkunskap (Skolverket, 2006a). De för alla obligatoriska gymnasiestudierna inkluderar naturvetenskap/naturkunskap i Danmark och Sverige, medan de i Finland består av separata kurser i biologi, fysik, kemi och geografi.

Den danska lärarutbildningen för lärare i klasserna 1-9 (10) är en fyraårig seminarieutbildning på kandidatnivå (240 ECTS). I Finland och Sverige är lärarutbildningen forskningsbaserad och en del av universitets- eller högskoleutbildningen. I Finland leder den till magisterexamen efter fem år (300 ECTS), men i Sverige varierar den beroende på nivå och inriktning. Grundnivån i lärarexamen i Sverige (SFS, 2007) omfattar 180-210 ECTS och ger kompetens för förskola, förskoleklass, fritidshem och grundskolans tidigare år. För en avancerad nivå för grundskolans senare år och gymnasieskola behövs 240-330 ECTS. I Danmark och Sverige (för åk 1-9) kan lärarstuderandes ingångsnivå vara låg, medan nivån i Finland anses vara relativt hög som en följd av speciella antagningsprov och lärarutbildningens popularitet. Däremot har lärarutbildningen i Sverige och Danmark låg status och låga inträdeskrav (Komparativt studium af de nordiske læreruddannelser, 2009; SOU, 2009). Bestämmelse angående ämneskunskap inom lärarexamen finns klarast beskrivet i svensk högskoleförordning, där de studerande ska "visa sådan kunskap i ämnen eller inom ämnesområden som krävs för den verksamhet som utbildningen avser, inbegripet kunskap om ämnets eller ämnesområdets vetenskapliga grund, och om relevanta metoder inom verksamheten samt visa insikt om aktuella forskningsfrågor" (SFS, 2007, s. 3). Detta motsvarar innehållet i vår definition om baskunskap.

\section{Vad läroplaner och övriga styrdokument i Norden betonar angående människans biologi}

De styrdokument som skall ge ramarna för undervisningen i skolan har olika omfattning och preciseringsgrad i de nordiska länderna. Danmark har ett flertal ämnesspecifika styrdokument, där både mål och innehåll preciseras. Det nyaste styrdokumentet för grundskolan, Fælles Mål 2009, omfattar nya mål och innehållsbeskrivningar för förskolan och reviderar därmed "fagformål, slutmål, trinmål og læseplaner for skolens fag og emner". Undervisningen i gymnasiet styrs av speciella vägledningar på olika nivåer inom ämnena. I Finland finns både omfattningen och innehållet preciserade i de nationella läroplanerna för grundskolan respektive gymnasiet, medan de i Sverige beskrivs som allmänna mål i läroplanen, kompletterade med programmål och ytterligare preciserade i separata kursplaner. Kunskap kommer till uttryck i olika former, såsom fakta, förståelse, färdighet och förtrogenhet. De svenska nationella kursplanerna anses dock vara medvetet formulerade med ett stort tolkningsutrymme, vilket gör innehållet svårt att utläsa (Nyström, 2007).

Målen för människans biologi i de tre ländernas styrdokument för gymnasiet och grundskolans olika stadier används i denna studie som grund till vad lärarstuderande väntas kunna efter skolan respektive vad de som lärare bör kunna (se översikten i tabell 1). De danska målen om människans biologi är preciserade på en mycket noggrannare nivå än vad som finns utskrivet i de finländska och svenska styrdokumenten. Dessutom omfattar de danska målen sambanden mellan de olika organsystemen, betonar helhetsförståelse och ger även anvisningar om både innehåll och metoder för att nå målen. De finländska läroplanerna betonar kännedom om enskilda organ på alla stadier, medan de svenska styrdokumenten fokuserar på hur dessa organ fungerar tillsammans. 
Tabell 1. Kunskapsmålen inom människans biologi enligt respektive lands styrdokument (1-10), det vill säga vad eleven skall kunna eller känna till efter genomgånget stadium.

\begin{tabular}{|c|c|c|c|}
\hline Stadium & Danmark & Finland & Sverige \\
\hline Gymnasium & $\begin{array}{l}\text { Känna till människans fysi- } \\
\text { ologi, översikt av kroppens } \\
\text { organsystem samt ett urval } \\
\text { av organsystemens uppbyg- } \\
\text { gnad och funktion' }\end{array}$ & $\begin{array}{l}\text { Känna till grunddragen } \\
\text { i människans anatomi } \\
\text { Kunna redogöra för } \\
\text { huvuddragen i män- } \\
\text { niskocellens differen- } \\
\text { tieringsprocess samt } \\
\text { för vävnadernas och } \\
\text { organens byggnad och } \\
\text { för hur de fungerar }\end{array}$ & $\begin{array}{l}\text { Ha kunskap om regler- } \\
\text { ing av och samspel } \\
\text { mellan människans } \\
\text { organsystem. }{ }^{4} \\
\text { Kunna beskriva den } \\
\text { levande organismens } \\
\text { byggnad och funktion } \\
\text { från molekylär nivå till } \\
\text { organnivå. } 5\end{array}$ \\
\hline Årskurs 7-9 & $\begin{array}{l}\text { (Efter åk 9) kunna beskriva } \\
\text { och förklara väsentliga krop- } \\
\text { psfunktioner. } \\
\text { (Efter åk 8) Kunna beskriva } \\
\text { funktionerna och samman- } \\
\text { hangen mellan skelettet, } \\
\text { muskler, sinnen och nervsys- } \\
\text { tem, redogöra för viktiga } \\
\text { funktioner hos inre organ } \\
\text { och deras inbördes samspel; } \\
\text { upptagning av näring och } \\
\text { energi; känna till nerv- och } \\
\text { hormonsystem. }{ }^{6}\end{array}$ & $\begin{array}{l}\text { (Efter åk 9) kunna } \\
\text { beskriva hur män- } \\
\text { niskans viktigaste } \\
\text { vävnader, organ och or- } \\
\text { gansystem är uppbyg- } \\
\text { gda och deras funktion } \\
\text { i huvuddrag7 }\end{array}$ & $\begin{array}{l}\text { (Efter åk 9) ha kän- } \\
\text { nedom om den egna } \\
\text { kroppens organ och } \\
\text { organsystem samt hur } \\
\text { de fungerar tillsam- } \\
\text { mans }^{8,9}\end{array}$ \\
\hline Årskurs 1-6 & $\begin{array}{l}\text { (Efter åk 6) kunna beskriva } \\
\text { människans organsystem }{ }^{10} \\
\text { (Efter åk 4) kunna beskriva } \\
\text { människans sinnen och } \\
\text { kroppsfunktioner }^{10} \\
\text { (Efter åk 2) känna till män- } \\
\text { niskans sinnen och kunna } \\
\text { undersöka enkla kropps- } \\
\text { funktioner }{ }^{10}\end{array}$ & $\begin{array}{l}\text { (Efter åk 6) kunna i } \\
\text { huvuddrag beskriva } \\
\text { människans byggnad } \\
\text { och livsfunktioner } \\
\text { (Efter åk 4) kunna } \\
\text { namnge människans } \\
\text { viktigaste kroppsdelar } \\
\text { och centrala livsfunk- } \\
\text { tioner }^{7}\end{array}$ & $\begin{array}{l}\text { (Efter åk 5) känna till } \\
\text { viktiga organ i den } \\
\text { egna kroppen och } \\
\text { deras funktion } \\
8,9\end{array}$ \\
\hline Styrdokument & $\begin{array}{l}\text { Vejledning 2008: Biologi } \\
\text { C-nivå'; } \\
\text { Fælles Mål 2009: Bi6; Fælles } \\
\text { Mål 2009: N/T10 }\end{array}$ & $\begin{array}{l}\text { GGL } 2003 \text { för alla²; } \\
\text { GGL 2003, valbar Bi43; } \\
\text { GLGU 20047 }\end{array}$ & $\begin{array}{l}\text { Skolverket 2006a: } \mathrm{Bi}^{-B^{4}} \\
\text { Skolverket 2006a: } \\
\text { NK-B5; } \\
\text { Skolverket 20008 } \\
\text { Skolverket2006b: } \\
\text { LPO949 }^{9}\end{array}$ \\
\hline
\end{tabular}




\section{KUNSKAP OCH MISSUPPFATTNINGAR OM MÄNNISKOKROPPEN}

Tidigare forskning visar att såväl elever som en del av deras lärare har svårigheter att bilda en helhetsuppfattning om människans anatomi och fysiologi (Andersson, 2008; Andersson, Bach, Olander \& Zetterqvist, 2004; Reiss \& Tunnicliffe, 2001; Reiss m.fl., 2002). Missuppfattningar är allmänna redan hos blivande lärare (Andersson, 2008; Palmberg m.fl., 2008; Palmberg \& Svens, 2010). Enligt en nationell utvärdering i Sverige (Frändberg \& Bach, 2009) syns skillnaden mellan lärare som har och som inte har NO-ämnen i sin examen bäst inom undervisning av delområdet "Kroppens viktigaste struktur och funktion hos människan". Lärarens egen förståelse är av överordnad betydelse för vad deras elever får för möjligheter att lära sig (Helldén, Jonsson, Karlefors \& Vikström, 2010; Vikström, 2005).

\section{Elevers kunskaper och missuppfattningar om människokroppen}

Enligt TIMSS 2003 har $95 \%$ av svenska 15-åriga elever en relativt låg kunskapsnivå om människokroppen och om grundläggande fakta i biologi (Nyström, 2007). Det finns ett stort antal större och mindre undersökningar från olika länder, där elevers kunskaper om människokroppen undersökts med hjälp av teckningar, ofta kompletterade med förklarande texter, påståenden, flervalsfrågor och intervjuer. Tyvärr går det inte att jämföra resultaten, eftersom de är utförda på många olika sätt och har dessutom tolkats olika beroende på kulturella skillnader. Resultaten har speciellt påverkats av graden av exakthet i de instruktioner som getts i samband med undersökningen (Prokop, Fančovičová \& Tunnicliffe, 2009). Några exempel och försiktiga generaliseringar om elevers kunskaper kan dock lyftas fram. Förskolelever och elever i 7-8 års ålder känner före skolundervisningen till att hjärnan finns i huvudet och behövs för att kunna tänka (Jeronen, Niemitalo, Jeronen \& Korkeamäki, 2010; Óskarsdóttir, 2006). Elever i 10-12 års ålder förstår dessutom att hjärnan reglerar fysiologi och känsloreaktioner (Lundin, 2007; Bartoszeck m.fl., 2008). Elever i åldern 7-15 känner bäst till skelettet, matsmältnings- och andningsorganen och sämst muskulaturen, blodcirkulationssystemet och exkretionssystemet (Granklint Enochson, Helldén \& Lindahl, 2008; Pojaghi, 1996; Reiss m.fl., 2002; Teixeira, 2000; Tunnicliffe, 2004).

Bristande förståelse och missuppfattningar finns i alla ålderskategorier. Matsmältningsorgan beskrivs av barn i åldern 4-6 som ett tomt utrymme i magen, medan elever i åldern 8-10 förklarar matsmältningssystemet som ett rör med olika avdelningar genom kroppen (Carvalho, Silva, Lima, Coquet \& Clément, 2004; Teixeira, 2000) eller som fritt flytande organ utan förbindelse med varandra (Cuthbert, 2000). Elever i åldern 11-14 känner till namnen på olika organ, men har svårt att beskriva former och platser för dem samt vilka funktioner de har (Cerrah Özsevgeç, 2007). Att nedbrytningen av födan börjar och slutar i magsäcken samt att vatten och andra drycker hjälper till att bryta ned den är exempel på de missuppfattningar som förekommer hos många 10-15 åringar (Cakici, 2005; Granklint Enochson m.fl., 2008).

Majoriteten av svenska 15-åringar väljer bland svarsalternativen ett enkelt blodomlopp i stället för dubbelt och $30 \%$ dessutom ett alternativ som inte har lungan med. Hjärtat ansågs ha fler funktioner än det faktiskt har, bl.a. att det tillverkar, renar eller syresätter blod (Andersson m.fl., 2004; Cerrah Özsevgec, 2007). Människokroppens organ och organsystem uppfattas även hos äldre elever som separata, d.v.s. kunskapen inkluderar inte en helhet med välintegrerade delsystem på olika organisationsnivåer (Andersson, 2008; Cuthbert, 2000). De har dessutom svårt att koppla ihop blodsystemet med njurarnas funktion (Granklint Enochson, 2009; Granklint Enochson m.fl., 2008). På basis av forskningsresultat kunde dock en svag åldersrelaterad progression i förståelse konstateras. De yngre eleverna saknar ännu de flesta inre strukturer i sina fysiologiska förklaringar, medan elever i årskurs 9 har dem med, men förstår inte ännu fysiologin som ett integrerat organsystem (Andersson, 2008; Reiss m.fl., 2002). 


\section{Lärarstuderandes och lärares kunskaper och missuppfattningar om människokroppen}

Forskningen visar att även lärare och lärarstuderande har svårigheter att förstå matsmältningen eller respirationen som ett integrerat system (Andersson, 2008; Carvalho \& Silva, 2005; Clément, 2003; Sanders, 1993). Tyvärr finns det endast ett fåtal studier, där syftet varit att undersöka verksamma lärares kunnande i naturvetenskaper (Kärrqvist \& Frändberg, 2008) eller hur lärares missuppfattningar påverkat elevers inlärning. Två äldre studier (Sanders 1993; Yip 1998) visar nämligen stark korrelation mellan lärares och elevers likartade missuppfattningar. Läraren kan med andra ord vara en direkt och huvudsaklig orsak till att elevers missuppfattningar i naturvetenskaper sprids och befästs (Yip, 1998). Nedanstående få exempel får belysa problematiken med lärares och lärarstuderandes missuppfattningar eller avsaknad på kunskap och förståelse inom människans biologi.

En del lärare och lärarstuderande kopplar inte matsmältningen till blodcirkulationen, inte heller förstår de förhållandet mellan matsmältning, cirkulationssystem och urinsystem (Abu-Hola, 2004; Carvalho, Dantas \& Clément, 2004; Clément, 2003; Prokop \& Fančovičová, 2006; Reiss \& Tunnicliffe 2001; Yip, 1998). Vätskans och födans väg beskrevs av en del första årets studerande i Frankrike antingen från munnen direkt till urinorgan eller som två separata system för vätskor respektive fast föda (Clément, 2003). I England konstaterades att de första årets lärarstuderande som inte studerar naturvetenskaper, har en sådan kunskapsnivå beträffande människans biologi som motsvarar nioåringars nivå (Reiss \& Tunnicliffe, 2001).

\section{FORSKNINGSFRÅGOR}

Blivande lärares förkunskaper, d.v.s. de kunskaper de har vid inledningsfasen av lärarutbildningen, inom temat människans biologi undersöktes i tre nordiska länder med hjälp av följande forskningsfrågor:

1. Anser blivande lärare för årskurs 1-6 att människans biologi utgör baskunskap, d.v.s. sådan ämneskunskap om människans anatomi och fysiologi som de kommer att behöva som lärare enligt aktuella styrdokument?

2. Vilken kunskap har blivande lärare om människans biologi, i relation till det som stadgas för biologi eller naturkunskap enligt läroplan och övriga styrdokument i skolan?

3. Vilka faktorer kan förklara skillnader i kunskap om människans biologi mellan lärarstuderande i de tre länderna samt enskilda lärarstuderande emellan?

\section{MATERIAL OCH METODER}

Vid insamlingen av forskningsmaterial kombinerades kvantitativa och kvalitativa metoder. I undersökningen deltog totalt 379 första årets lärarstuderande, varav 70 från två lärarutbildningsenheter i Danmark, 188 från tre enheter i Finland och 121 från två enheter i Sverige. Kunskapsnivån hos första årets studerande diagnostiserades för att i undervisningen vid lärarutbildningen kunna beakta startnivån och eventuella missuppfattningar. Alla besvarade en tvådelad enkät, ett s.k. baskunskapstest, där del I inkluderade sex sådana flervalsfrågor om temat människans biologi som motsvarar innehållet för undervisning för årskurserna 1-6 inom respektive lands styrdokument (se tabell 2). Del II utgjorde en utvärderingsdel där studerande bl.a. skulle ange huruvida de ansåg att frågetemat utgör baskunskap eller inte. På basis av enkätpoängen i kunskapsdelen valdes totalt 48 studerande till en semistrukturerad intervju, där de med sina enkätsvar som grund under ca 30 minuter fick redogöra för hur de tänker i de utvalda kunskapsfrågorna inom människans biologi och hur viktigt de anser att det är för dem att ha kunskap om människans biologi. För att få fram eventuella faktorer som påverkat studerandes kunskap fick de ytterligare vid intervjun förklara om intresset för och inställningen till människans biologi och hälsofrågor samt omfattningen av och intresset för den skolbiologi de deltagit i. De intervjuade från respektive land representerade i lika proportion bägge könen samt både hög- och lågpresterande studerande enligt kunskapstestet. 
Tabell 2. Testfrågor och svarsalternativ om människan och hälsan

\begin{tabular}{|l|l|}
\hline Fråga & Svarsalternativ a-d (det rätta alternativet kursiverat) \\
\hline $\begin{array}{l}\text { 1. Vilket organ reglerar } \\
\text { vatten- och salthalten i } \\
\text { kroppen? }\end{array}$ & a. njuren, b. levern, c. urinblåsan, d. tarmen \\
\hline $\begin{array}{l}\text { 2. Vilket av följande } \\
\text { påståenden om blodcirku- } \\
\text { lationen är riktigt? }\end{array}$ & $\begin{array}{l}\text { a. Blodcirkulationen deltar i immunförsvaret, b. Blodcirkulationen } \\
\text { deltar i värmeregleringen, } \\
\text { c. Blodcirkulationen deltar i urinbildningen, d. Alla ovanstående } \\
\text { påståenden är riktiga. }\end{array}$ \\
\hline $\begin{array}{l}\text { 3.Vilket av följande } \\
\text { påståenden om levern är } \\
\text { riktigt? }\end{array}$ & $\begin{array}{l}\text { a. Levern utsöndrar galla. b. Alla ämnen vi äter och dricker passerar } \\
\text { via levern. c. Levern deltar i regleringen av blodsockerhalten. d. Alla } \\
\text { ovanstående påståenden är riktiga. }\end{array}$ \\
\hline $\begin{array}{l}\text { 4. Vilket av följande } \\
\text { påståenden om balanssin- } \\
\text { net är riktigt? }\end{array}$ & $\begin{array}{l}\text { a. Balanssinnet finns i mellanörat. b. Balanssinnet registrerar huvu- } \\
\text { dets rörelser. c. Balanssinnet registrerar musklernas rörelser. } \\
\text { d. Alla ovanstående påståenden är riktiga }\end{array}$ \\
\hline $\begin{array}{l}\text { 5. Vilket av följande } \\
\text { påståenden om sköldkör- } \\
\text { teln är riktigt? }\end{array}$ & $\begin{array}{l}\text { a. Sköldkörteln ligger under struphuvudet. b. För att sköldkörteln ska } \\
\text { kunna producera hormoner behöver den jod. } \\
\text { c. Sköldkörtelhormonerna styr ämnesomsättningen och är viktiga } \\
\text { för tillväxt och psykisk utveckling. d. Alla ovanstående påståenden är } \\
\text { riktiga. }\end{array}$ \\
\hline $\begin{array}{l}\text { 6. Vilka funktioner svarar } \\
\text { stora hjärnan för? }\end{array}$ & $\begin{array}{l}\text { a. kognitiva funktioner såsom tanke och minne, b. balans och } \\
\text { koordinering av rörelser, c. livsupprätthållande funktioner såsom } \\
\text { andning och blodcirkulation d. alla ovanstående funktioner }\end{array}$ \\
\hline
\end{tabular}

Enkätsvaren analyserades med hjälp av SPSS 14.0 för Windows och Excel parallellt. Intervjuerna transkriberades ordagrant, lästes av fyra forskare och grupperades enligt tema. Beskrivande citat plockades som exempel på hur studerande förklarar olika organsystem och deras funktioner. Reliabiliteten och validiteten i enkätundersökningen försäkrades med hjälp av ett pilottest för en grupp lärarutbildare i naturvetenskap samt den utvärdering som studerande själva gjorde beträffande frågornas entydighet och svarsalternativens relevans. Reliabiliteten i den semistrukturerade intervjuundersökningen uppnåddes genom att först skapa en detaljerad intervjumanual med frågor och sedan pilottesta den. Samtidigt tränades intervjutekniken. Fyra enskilda bedömare användes vid tolkningen av de öppna svaren.

\section{RESULTAT}

Resultaten redovisas enligt de tre huvudfrågorna parallellt med enkät- och intervjusvar samt belyses med beskrivande utsagor om vad studerande uppfattar som baskunskap och hur de förstår och förklarar funktionerna i blodcirkulationen. Blodcirkulationen valdes som exempel, eftersom den har en mycket central funktion inom människans biologi. Faktorer som eventuellt påverkat studerandes förståelse analyseras på basis av den omfattning av temat människans biologi de haft i skolan samt deras intresse för människans biologi och hälsofrågor. Citat från intervjuerna följs av en kod, till exempel Dk7, Fm11 eller Sk1, där "D", "F" och "S" står för land (Danmark, Finland respektive Sverige), "k" för kvinna, "m" för man och siffran är respondentens nummer i intervjukoden. Citaten är ordagranna eller noggrant översatta. 


\section{Baskunskap inom människans biologi}

Över $70 \%$ av alla studerande ansåg att de tillfrågade ämnesområdena (frågorna 1-6 i tabell 2) utgör baskunskap (se figur 1), d.v.s. sådan ämneskunskap som de som lärare kommer att behöva för att kunna undervisa biologi eller naturkunskap i skolan. Kunskap om sköldkörteln ansågs dock av $40 \%$ vara på en fördjupad nivå. Det fanns dock tydliga landvisa skillnader. För närmare $90 \%$ av de finländska studerandena är människans biologi definitivt baskunskap, medan motsvarande medeltal för de svenska och danska studerandena var $62 \%$ respektive $42 \%$. Endast ca $30 \%$ av de danska studerandena ansåg sig behöva kunskap om balanssinnet och sköldkörteln.

Vid intervjun framkom flera orsaker till varför människans biologi definitivt är baskunskap. De allmännaste orsakerna var att man själv måste förstå för att kunna undervisa i temat eller värna om sin egen hälsa:

[...], men sådana saker som t.ex. ansluter sig till egen hälsa borde man nog kunna. Och om inte läraren kan, så undervisar hon inte heller gärna om det och sedan kan inte eleverna det heller (Fk5)

Det är ju viktigt att kunna ta hand om sig, att förstå sin kropp. (Sm8)

En del studerande ansåg att det dessutom hör till lärarens eller alla människors allmänbildning.

Det fanns även motsatta åsikter om en och samma funktion så som blodcirkulation:

[...] det är sånt man borde kunna (Fm1),

medan en annan uttryckte sig på följande sätt:

Blodkarcirkulation. Det ved jeg ikke, hvad jeg skal bruge til. (Dm3)

Enligt några studerande är dock människans biologi inte baskunskap. Om de ändå måste undervisa om ämnet, anser de sig kunna lösa problemet före lektionen.

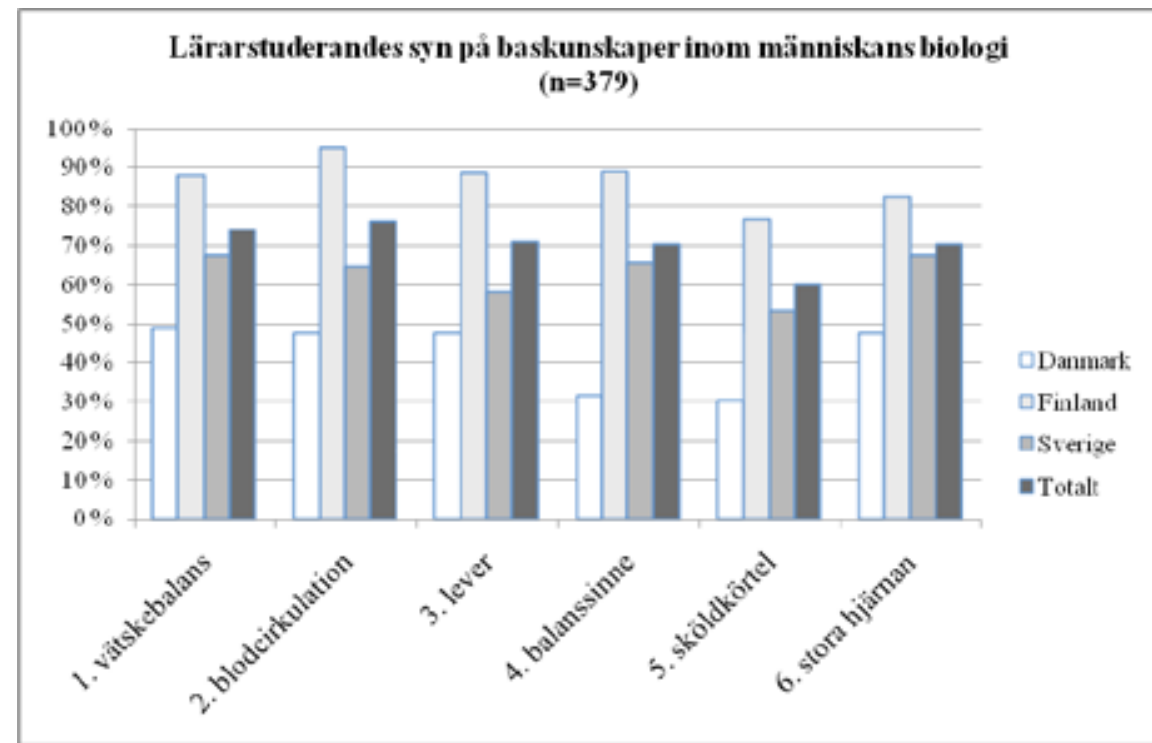

Fig. 1. Baskunskap inom människans biologi i de tillfrågade områden 1-6 i tabell 2 enligt danska, finländska och svenska lärarstuderande.

\section{Lärarstuderandes förkunskaper och missuppfattningar om människans biologi}

Lärarstuderande hade överlag en låg kunskapsnivå om människans biologi. Mindre än hälften kunde svara rätt på de flesta frågorna (se figur 2). Bäst kunde de frågan om organ som reglerar vattenoch salthalten i kroppen (fråga 1). Totalt $75 \%$ hade valt rätt alternativ för denna fråga, medan 
endast $6 \%$ kunde svara rätt på frågan om balanssinnet (fråga 4). Leverns olika funktioner (fråga 3) var också oklara för en stor majoritet av de studerande (79 \%). Lärarstuderande i Finland presterade totalt sett något bättre svarsfrekvens på alla frågor (42\%) än svenska (34 \%) och danska studerande $(30 \%)$.

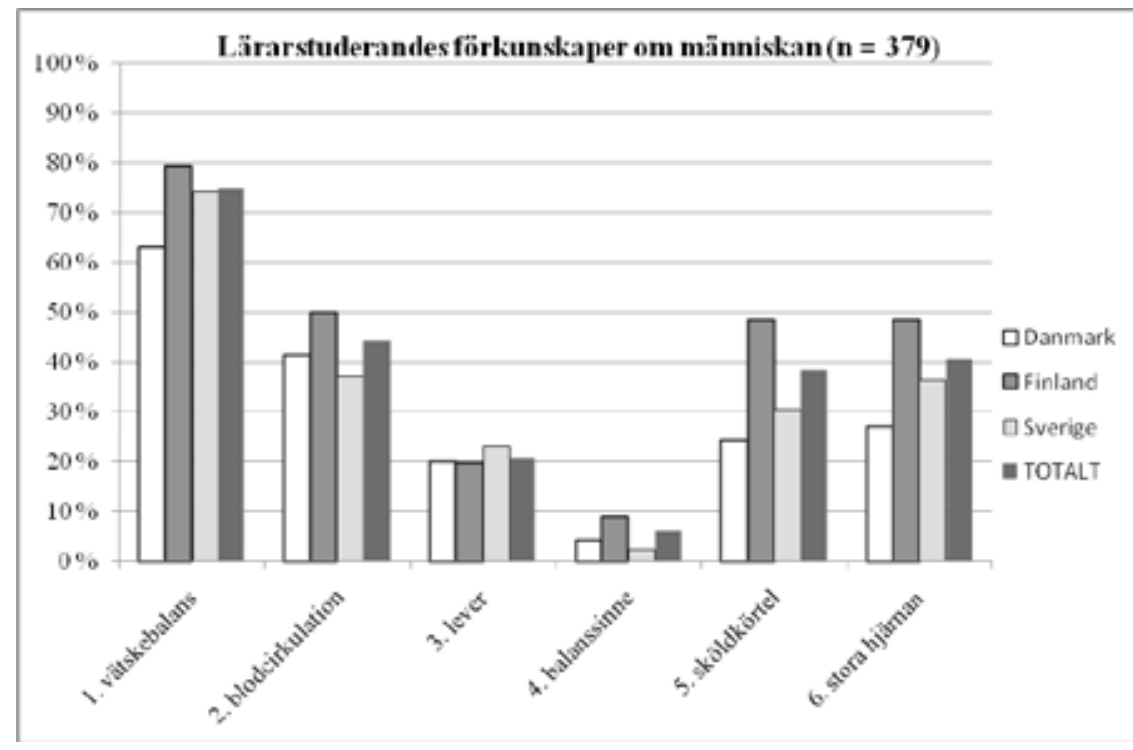

Fig. 2. Andelen rätta svar för de sex frågorna $i$ tabell 2 om människans biologi hos danska, finländska och svenska lärarstuderande. De rätta svaren per fråga anges i procent per land samt totalt.

Eftersom kunskapstestet bestod av flervalsfrågor klargörs härefter hur lärarstuderande valt de olika alternativen för respektive fråga. De svarsalternativ som inkluderade många funktioner för ett organ eller organsystem användes i syfte att mäta studerandes helhetskunskap och säkerheten beträffande deras svar. Av figur 3 framgår att totalt $75 \%$ av de studerande kände till att njurarna reglerar vatten- och salthalten i kroppen (fråga 1, alternativ a), medan $11 \%$ föreslog att ansvaret ligger hos levern (b), ytterligare $10 \%$ föreslog urinblåsan (c) och $3 \%$ tarmen (d). Endast $44 \%$ av de studerande kände till att blodcirkulationen har många funktioner (fråga 2, alternativ d), d.v.s. att den bl.a. deltar i kroppens immunförsvar, värmereglering och urinbildning. Närmare $40 \%$ trodde att blodcirkulationen enbart deltar i värmeregleringen (b), $11 \%$ enbart i immunförsvaret (a) och $1 \%$ enbart i urinbildning (c).

Kunskapsnivån om leverns funktioner var låg. Totalt $21 \%$ kände till att levern har många funktioner (fråga 3, alternativ d). En dryg tredjedel (38 \%) ansåg att endast påståendet om att alla ämnen vi äter och dricker passerar via levern (b), var rätt, medan $17 \%$ endast kände till att levern utsöndrar galla (a) och $20 \%$ att levern bara deltar i regleringen av blodsockret (c). Beträffande balanssinnet hade nästan varannan studerande (49 \%) valt att placera balanssinnet i mellanörat (fråga 4, alternativ a). Totalt $6 \%$ kände till att balanssinnet registrerar huvudets rörelser (b), medan lika många antog att balanssinnet registrerar musklernas rörelser (c) och upp till $34 \%$ att alla ovanstående påståenden var rätta $(\mathrm{d})$.

Av de studerande svarade 38 \% rätt på frågan om sköldkörteln (fråga 5, alternativ d). De övriga ansåg att endast ett påstående var rätt, vilket betydde att ytterligare $15 \%$ kände till att sköldkörteln ligger under struphuvudet (a), 9 \% att sköldkörteln behöver jod för hormonproduktion (b) och $33 \%$ att sköldkörtelhormonerna är viktiga för tillväxt och psykisk utveckling (c). Mindre än hälften (40 \%) kände till att stora hjärnan svarar för kognitiva funktioner såsom tanke och minne 


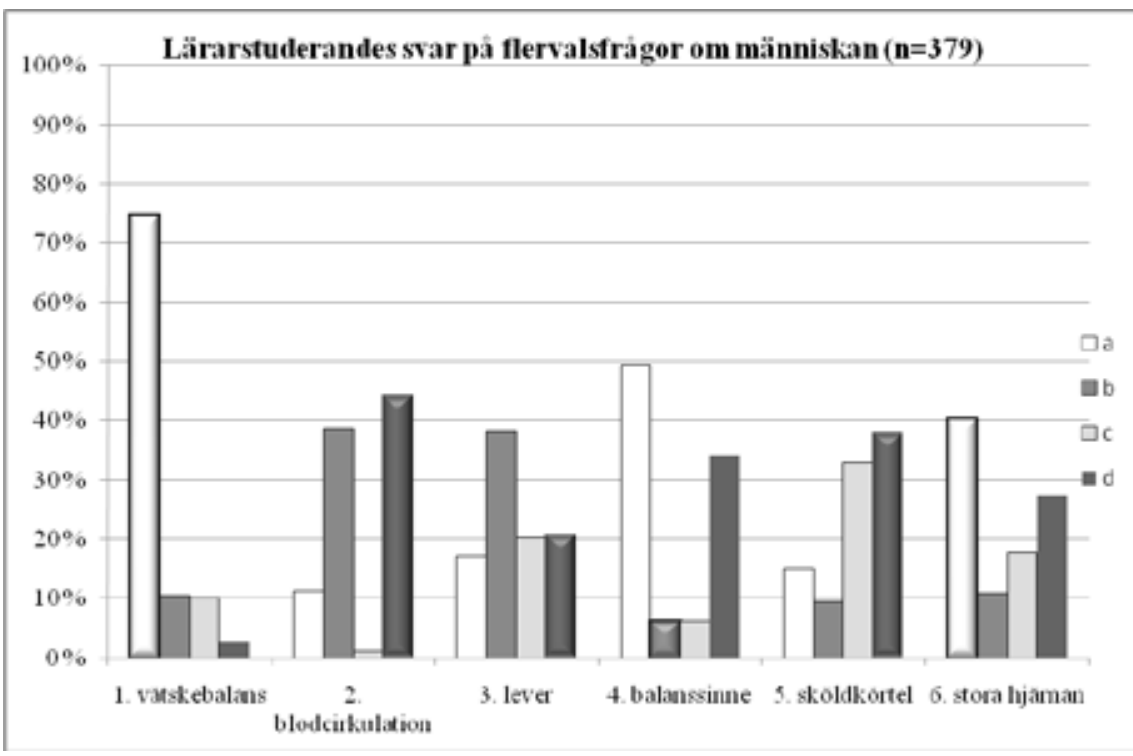

Fig. 3. Svarsprocenten för svarsalternativen a-d i de sex frågorna om människans biologi (se tabell 2) hos blivande lärare. De rätta svarsalternativen är markerade med 3D-staplar.

(fråga 6, alternativ a). $11 \%$ trodde att stora hjärnan svarar för balans och koordinering av rörelser (b), $18 \%$ att den svarar för andning och blodcirkulation (c) och totalt $27 \%$ antog att stora hjärnan har alla de ovannämnda funktionerna (d). Andelen studerande som inte alls svarade på frågorna varierade mellan två och fem procent per fråga (fig. 3).

\section{Lärarstuderandes kunskaper och missuppfattningar om blodcirkulation}

För att utesluta möjligheten att lärarstuderande bara har gissat sig till rätt svar (vilket alltid är en risk i tester med flervalsfrågor) utfördes en närmare granskning av svaren genom att intervjua totalt 48 studerande. De frågades hur säkra de var på sina svar och om de ville ändra sina tidigare svar. Därefter bads de med egna ord förklara hur de tänker beträffande de olika svarsalternativen i syfte att få fram hur de uttrycker sina kunskaper och eventuella missuppfattningar. Detta utfördes också med tanke på att i svarsalternativet "alla ovanstående" kunde studerande få rätt redan då de korrekt identifierat två av de tre funktionerna eller påståendena. Blodcirkulationen valdes som ett exempel, eftersom den har en mycket central funktion inom människans biologi och kräver förståelse av ett flertal livsviktiga funktioner, såsom immunförsvar, värmereglering och urinbildning. Det rätta alternativet $\mathrm{i}$ testet, d.v.s. att blodcirkulationen deltar $\mathrm{i}$ alla nämnda funktioner, hade valts av 32 av de intervjuade studerandena. De flesta studerande hade dock svårt att på ett tillfredsställande sätt förklara de olika funktionerna. Hur studerande förklarar de tre nämnda funktionerna beskrivs nedan och belyses ytterligare med några utvalda citat.

\section{Hur lärarstuderande förklarar värmeregleringen som en del av blodcirkulationens uppgifter}

Värmeregleringen (alternativ b) var den funktion som studerande kunde förklara bäst. Totalt 32 studerande $(67 \%)$ förklarade denna funktion någorlunda tillfredsställande eller åtminstone delvis rätt, medan resten (33\%) bara hade en känsla av att blodcirkulationen antingen har eller inte har någonting med värmeregleringen att göra.

En del studerande var mycket osäkra på sina svar och utgick endast från en känsla av att svarsalternativet kunde vara rätt. En del utsagor var direkt motsägelsefulla: 
Värmeregeringen har mycket att göra med att man svettas och på det viset kyls kroppen ner och det har ju ingenting att göra med blodcirkulationen. Men det som jag hade tänkt är att man kan få upp värmen i och med att blodet cirkulerar. (Fm2)

Oftast förklarade studerande värmeregleringen med hjälp av egna erfarenheter eller exempel från vardagen, vilka dock saknade den strikt vetenskapliga förklaringen. Uttrycket om man fryser så har man dålig blodcirkulation var väl känt bland studerande. Endast tre studerande kunde förklara värmeregleringen med hjälp av vad som händer i blodkärlen:

[...] att när det är kallt så drar sig blodet från ytliga blodkärl så att värmen hålls i viktiga organ, och på motsvarande sätt, när det är varmt, ökar blodcirkulationen i de ytliga blodkärlen. (Fm6)

\section{Hur lärarstuderande förklarar immunförsvaret som en del av blodcirkulationens uppgifter}

Av de intervjuade inkluderade 30 studerande immunförsvaret till blodets uppgifter (alternativ a), men endast nio av dem kunde förklara det med hjälp av vita blodkroppar som kroppens försvar mot bakterier:

Blodet innehåller vita blodkroppar som hör till immunförsvar, eller transporterar de där vita

blodkropparna runt kroppen till de ställen de behövs (Fm7)

De 21 av dem som nämnde vita blodkroppar kunde dock inte förklara dessas uppgift och en del av dem nämnde dessutom både vita och röda blodkroppar som en del av immunsystemet:

Alltså immunförsvaret, då tänker jag på det här med röda och vita blodkroppar och det är ju

någonting som finns i blodet. (Sk7)

Ytterligare 18 studerande hade ingen aning om vad immunförsvar är eller hade helt felaktiga förklaringar:

[...] och immunförsvaret, då tänker jag att det direkt att det är det där med hormonerna t.ex. att, med sköldkörteln [...]. (Sk11)

\section{Hur lärarstuderande förklarar urinbildningen som en del av blodcirkulationens uppgifter}

Sämst av de tre funktionerna kunde de studerande förklara urinbildningen. Totalt 38 av de intervjuade (ca $80 \%$ ) ansåg att alternativet c var fel eller antog att alternativet var rätt, även om de inte kunde förklara processen:

[...] jag kunde inte som koppla blodcirkulation som t.ex. med urinbildningen, jag förstår som

inte vad de kan ha för någon koppling till varandra överhuvudtaget (Sk11)

Endast åtta av de tjugo som valt alternativet c kunde förklara urinbildningen så att de nämnde slaggprodukter och njurar i processen. Ingen av dem kunde dock beskriva processen som helhet:

[...] och så tänkte jag att många ämnen, de här slaggprodukterna och så vidare, förs ju ut med

blodet och så vidare, det far ju via njurarna det också. (Vm6)

Dessutom var en del osäkra på eller hade t.o.m. missuppfattningar om vad som sker i urinbildningen:

Det är njurarna skulle jag säga för det är ju ändå liksom, det far ju ändå genom kroppen det här vad man har druckit och det far ju liksom i det här med tarmarna och det är ändå vid njurarna som det ändå spjälkas, nej det är tarmarna. Men ändå via de här njurarna som gör att det som blir det som kommer ut vid urinbildningen. (Fk4)

\section{Faktorer som kan ha påverkat blivande lärares kunskapsnivå}

Skillnaderna i kunskapsnivån mellan länderna kan delvis förklaras med de skillnader som förekommer i de tre ländernas gymnasieutbildning, men också med skillnader i antagningen till lärarutbildningen. Endast Finland ordnar en separat antagning baserad på slutbetyget från gymnasiet och lämplighetsintervjuer, medan Sverige och Danmark har en allmän antagning till universitetsstudier eller seminarieutbildning. Dessutom är lärarutbildningen populär i Finland och lockar därmed många studerande "av god kvalitet" (Komparativt studium af de nordiske læreruddannelser, 2009). För att få fram olika faktorer som eventuellt har påverkat kunskapsnivån hos enskilda lärarstuderande utreddes skillnader i deras intresse för människans biologi och hälsofrågor, fritidsintressen, favoritämnen i skolan samt omfattningen av och slutbetyget i biologi från gymnasiet. 
Det visade sig att de studerande inte alltid kom ihåg sina betyg och intressen från skoltiden. Dessutom behöver en avklarad kurs inte betyda att studerande verkligen har lärt sig det som kursen behandlat. Ytterligare faktorer som påverkar inlärningen är arbetssätt och undervisningsformer samt sättet att lära sig, men dessa undersöktes inte i detta sammanhang. På grund av det lilla antalet intervjuade $(n=48)$ är det inte möjligt att hitta entydiga, statistiskt hållbara korrelationer mellan de olika faktorerna. Däremot kan intervjusvaren exemplifiera några faktorer som inverkat på kunskapsnivån.

De intervjuade som tyckte att människans biologi var intressant och viktigt kunde även bättre förklara och motivera sina svar. Ytterligare visade det sig att dessa personer valt flera frivilliga kurser i biologi i gymnasiet och att de också hade ett berömligt slutbetyg i biologi samt ett fortsättningsvis stort intresse för ämnet. Några av dem hade dessutom biologi bland sina favoritämnen i gymnasiet. Däremot hade de personer som inte alls kunde förklara de olika funktionerna av blodcirkulationen inga valbara kurser i biologi samt både lågt intresse för och lågt slutbetyg i biologi. De tyckte att människans biologi är alltför teoretiskt och detaljrikt, rentav tråkigt, för att de kunde bli intresserade av det. Trots att dessa personer inte hade intresse för den teoretiska kunskapen om människans biologi, var de intresserade av sin egen hälsa och sitt välmående. Av de 48 intervjuade tyckte tio att egen hälsa är mycket viktig, 35 ganska mycket och endast tre att den är viktig men att de inte alltid tänker på den. Typiskt för de flesta var att de även hade fritidsintressen inom idrott eller gymnastik. De studerande som hade valt speciallinjer eller specialgymnasier, bortsett från naturvetenskapliga, tenderade att ha en lägre kunskapsnivå än övriga. De lägsta poängen i kunskapstestet erhölls nämligen av studerande som kom från idrotts- eller bildkonstgymnasier eller som gått en speciallinje, såsom drama- eller teaterlinje.

\section{DISKUSSION OCH SLUTSATSER}

Resultaten från denna undersökning bekräftar tidigare undersökningar, men lyfter även fram ytterligare brister i lärarstuderandes kunnande inom människans biologi. Några av de studerande kommer att undervisa detta temaområde utan mer utbildning och trots att deras kunskap er osäker och inkluderar många missuppfattningar. De saknar helhetsförståelse av de integrerade organsystemen, vilket gör det svårt för dem att i sin egen undervisning kunna förklara och handleda eleverna meningsfullt både ämnesmässigt och didaktiskt (se även Andersson, 2008). Skillnaderna i lärarstuderandes kunskaper och uppfattning av vad som är baskunskap bygger bl.a. på dessa länders olika sätt att locka och välja lärarstuderande. Intresset för klasslärarutbildningen är i Finland mycket större än i Sverige och Danmark. Det finländska urvalssystemet gynnar sökande som har höga skolbetyg (Komparativt studium af de nordiske læreruddannelser, 2009). Intressant att notera är även att ett stort antal av de undersökta lärarstuderandena angav idrott och gymnastik som både favoritämne och viktigaste fritidsintresse. Deras stora intresse för egen hälsa och eget välmående inkluderade dock inte kunskap om människans biologi, d.v.s. grunden för att kunna förstå hur kroppen fungerar.

Skillnaderna i ländernas skolkultur syns också i resultaten. Att de finländska lärarstuderandena klarade sig bättre än de svenska och danska i de flesta kunskapsfrågorna kan förklaras av att finländska styrdokument betonar kunskap och fakta betydligt mer än motsvarande svenska och danska. Människans biologi är dock ett undantag. Trots att danska styrdokument betonar kunskapsmålen mest av dessa länder, kunde de danska studerandena detta tema sämst. Motsvarande skillnader i kunskapsnivån mellan dessa länders elever förekommer i t.ex. PISA-utvärderingar (Arinen \& Karjalainen, 2007; Skolverket, 2009), som visserligen gäller elever i årskurs 8. I Finland undervisas denna årskurs enbart av ämneslärare, vilkas utbildning betonar ämneskunskaper, medan motsvarande årskurs i Sverige och Danmark ofta undervisas av lärare som genomgått en lärarutbildning som motsvarar klasslärarutbildningen (Frändberg \& Bach, 2009; Danmarks Lærerforening, 2010). 


\section{Lärmiljön och lärarens professionella utveckling}

Lärandet är starkt förknippat med lärmiljön och påverkas av affektiva faktorer, såsom intresse, attityder och motivation (Duit \& Treagust, 2003; Sinatra \& Pintrich, 2003). Det finns ett klart samband mellan kunskaper och intresse (Palmberg \& Svens, 2010; Schiefele, Krapp \& Winteler, 1992). Upplevelser i tidig barndom har en stor inverkan på det framtida intresset. Känslor av glädje och nyfikenhet kombinerade med att lyckas i de yngre åren leder med all sannolikhet till ett bestående intresse för naturvetenskap (Osborne, Simon \& Collins, 2003). Interaktionen mellan lärare och elev är därför mycket viktig. Speciellt viktigt har det varit för dem som inte redan varit "frälsta" för ämnena.

Lärares kunskaps- och färdighetsnivå betonas i olika utredningar som en viktig del i elevers möjligheter att lära sig i skolan:

En förutsättning för att eleverna får en utbildning med god kvalitet är att lärarna har kunskap att utifrån målen för utbildningen planera och genomföra undervisning som tillgodoser varje elevs behov. För detta krävs såväl ämneskunskaper som didaktisk kompetens, d.v.s. att läraren har erforderliga sakkunskaper och förmågan att förmedla dessa kunskaper till eleverna och att stödja deras kunskapsutveckling (SOU, 2007, s. 178).

Ämneskunskaperna hjälper dessutom lärare att identifiera elevers vardagsuppfattningar och missuppfattningar. Diskussionerna har även kretsat kring integreringsfrågan, d.v.s. huruvida det naturvetenskapliga tänkandet och förståelsen av naturvetenskapliga fenomen utvecklas om undervisningen sker integrerat eller ämnesspecifikt. De senaste utvärderingarna (Kärrqvist \& Frändberg, 2008; Åström 2007) visar dock inga signifikanta skillnader mellan ämnesintegrerad och ämnesspecifik undervisning.

\section{Implikationer för lärarutbildning}

I enlighet med tidigare forskningsresultat (Abu-Hola, 2004; Andersson, 2008; Palmberg \& Svens 2010) förstärker denna undersökning vikten av att i inledningsfasen till lärarutbildningsprogrammen inkludera diagnostisering och bearbetning av blivande lärares missuppfattningar i naturvetenskaper. Lärarstuderande borde även som grund för sin egen undervisning bekanta sig med forskningsresultat om elevers missuppfattningar och orsakerna till dem. Den pedagogiska innehållskunskapen och lärarprofessionalismen borde därmed kunna ytterligare betona vikten av de strategier som är fruktbara för att utmana elevers förståelse. Eftersom människans biologi av lärarstuderande upplevdes som svår och alltför detaljerad, är det viktigt att utveckla undervisningen i riktning mot problembaserad, deltagande undervisning (se t.ex. Harrison, Hofstein, Eylon \& Simon, 2008; Yli-Panula 2005), som dessutom erbjuder autentiska undersökningar och inlärningssituationer (Ahopelto, Mikkilä-Erdman, Penttinen \& Anto, 2009). En jämnare fördelning av humanistiska och naturvetenskapliga områden vid lärarutbildningen kunde fungera som första hjälp. Lärarutbildningen borde m.a.o. inkludera mera tid för naturvetenskaperna, eftersom förståelse för dessa kräver en längre tid för att kunna utvecklas till det som är typiskt för dem, nämligen naturvetenskapligt tänkande (Utbildningsstyrelsen, 2009). Resultaten från denna diagnostisering av lärarstuderandes kunskapsbrister i och missuppfattningar om människans biologi (och övriga områden) i början av deras studier kunde användas som grund för att utveckla lärarprogrammen. Inom den fortsatta forskningen planeras motsvarande utredning då studerande är i slutstadiet av sina studier.

Vi tackar våra kolleger Birgitte Sperber och Göran Abel, som samlat in ytterligare material från Danmark och Sverige till denna forskning.

\section{REFERENSER}

Abell, S.K. (2007). Research on science teacher knowledge. I S. Abell \& N. Lederman (Red.) Research on science education (s. 1105-1149). Mahwah, NJ: Lawrence Erlbaum Associates. 
Abu-Hola, I. (2004). Biological science misconceptions amongst teachers and primary students in Jordan: diagnosis and treatment. The Internet Society. Advances in Learning, Commerce and Security 1, s. 109-118.

Ahopelto, I., Mikkilä-Erdman, M., Penttinen, M. \& Anto, E. (2009). Yhteyttäminen ja käsitteellinen muutos - interventio luokanopettajaopiskelijoilla. (Assimilation och begreppsändring - intervention hos klasslärarstuderande) Kasvatus, 40 (4), 307-316.

Andersson, B. (2008). Att förstå skolans naturvetenskap. Forskningsresultat och nya idéer. Lund: Studentlitteratur.

Andersson, B., Bach, F., Olander, C. \& Zetterqvist, A. (2004). Grundskolans naturvetenskap utvärderingar 1992 och 2003 samt en framtidsanalys. Serie NA-spektrum 24. Mölndal: Göteborgs universitet, Inst. för pedagogik och didaktik.

Andrée, M. (2007). Den levda läroplanen. En studie av naturorienterande undervisningspraktiker i grundskolan. Lärarhögskolan i Stockholm. Studies in Educational Sciences 97. Stockholm: HLS Förlag.

Arinen, P. \& Karjalainen, T. (2007). PISA06. PISA 2006 ensituloksia 15-vuotiaiden koululaisten luonnontieteiden, matematiikan ja lukemisen osaamisesta. (PISA 2006 De första resultaten om 15-åriga elevers kunnande i naturvetenskaper, matematik och läsning) Undervisningsministeriets publikationer 2007: 38. Helsingfors: Universitetstryckeriet.

Bartoszeck, A.B., Bartoszeck, F.K., Clément, P. \& Abramson, C.I. (2008). Investigating children's conceptions of the brain. ERIDOB conference 2008. Tillgänglig 2010-03-08: http://www. science.uu.nl/eridob/acceptedproposals/areasynopsis.aspx?g=0200d2bb-797e-4ba2-a9808 f10dfcb53ad.

Cakici, Y. (2005). Exploring Turkish upper primary level pupils' understanding of digestion. International Journal of Science Education, 27(1), 79-100.

Carvalho, G.S. \& Silva, R. (2005). First images in primary school textbooks as didactical obstacles in the construction of science concepts: the example of digestion. Symposium on Critical analysis of texts and images in Biology textbooks. In Proceedings of ESERA'05. Barcelona, 28 de Agosto a 1 de Setembro. Tillgänglig 2010-03-08: http://repositorium.sdum.uminho.pt/ bitstream/1822/4656/1/ESERA-Symp\%20First\%20images\%20textbooks.pdf.

Carvalho, G.S., Dantas, C. \& Clément, P. (2004). Conceptions of digestion and their possible evolution. A study of primary school teachers and trainee teachers in Portugal. Presentation at the Fifth Conference of European Researchers in Didaktik of Biology -ERIDOB 2004, Patras, Greece.

Carvalho, G.S., Silva, R., Lima, N., Coquet, E. \& Clément, P. (2004). Portuguese primary school children's conceptions about digestion: identification of learning obstacles. International Journal of Science Education, 26 (9), 1111-1130.

Cerrah Özsevgeç, L. (2007). What do Turkish students at different ages know about their internal body parts both visually and verbally? Journal of Turkish Science Education, 4 (2), 31-44.

Clément, P. (2003). Situated conceptions and obstacles: the example of digestion and excretion. I D. Psillos, P. Kariotoglou, V. Tselfes, E. Hatzikraniotis, G. Fasspoopoulos \& M. Kallery (Red.) Science education research in a knowledge-based society. (s. 89-98). Dordrecht: Kluwer AcademicPublishers.

Cuthbert, A. (2000). Do children have a holistic view of their internal body maps? School Science Review, 82 (299), 25-32.

Danmarks Lærerforening. (2010). Undersøgelse af undervisningen i naturfagene. Tillgänglig 2010-08-18: www.dlf.org.

Duit, R. \& Treagust, D.F. (2003). Conceptual Change. A powerful framework for improving science teaching and learning. International Journal of Science Education, 25 (6), 671-688.

Et Foelles Løft. (2008). Rapport fra arbejdsgruppen til forberedelse af en National Strategi for Natur, Teknik og Sundhed, 15. februar 2008. Tillgänglig 2011-01-21: www.uvm.dk/ /media/ Files/Aktuelt/PDF08/080215_nts.ashx 
Finke, E., Klee, R. \& Berck, K-H. (1998). Analysis of the development of pupils' interests in biology: especially in animals, plants, human biology, conservation, and pollution control. I H. Bayrhuber, \& F. Brinkman (Red.) What - Why - How? Research in didaktik of biology. Proceedings of the first conference of European researchers in didaktik of biology (ERIDOB), s. 293-300. Kiel: Institut für die Pädagogik der Naturwissenschaften.

Frändberg, B. \& Bach, F. (2009). Naturorienterande ämnen $i$ årskurs 4. En analys av lärares och elevers uppfattningar om ämnesinnehåll och undervisning $i$ TIMSS 2007. Analysrapport till 323. Skolverket.Tillgänglig 2010-03-08: http://www.skolverket.se/publikationer?id=2288.

Falles Mål. (2009). 1) Biologi. Tillgänglig 2010-04-09: http://www.faellesmaal.uvm.dk/fag/Biologi/trinmaal_synoptisk.html, 2) Natur/Teknik: http://www.faellesmaal.uvm.dk/fag/Natur_ teknik/trinmaal_synoptisk.html.

Granklint Enochson, P. (2009). Elevers föreställningar om kroppens organ och kroppens hälsa utifrån ett skolsammanhang. Studies i Science and Technology Education No 25. Linköping universitet; licentiatavhandling (The Swedish National Graduate School in Science and Technology Education, FontD).

Granklint Enochson, P., Helldén, G. \& Lindahl, B. (2008). Student understanding about water transport in the human body and why water is healthy. I A. Macdonald (Red.) Proceedings of the $9^{\text {th }}$ Nordic Research Symposium on Science Education 11 $11^{\text {th }}-15^{\text {th }}$ June 2008, (s. 131-133). Reykjavik, Iceland.

GGL. (2003). Grunderna för gymnasiets läroplan. Helsingfors: Utbildningsstyrelsen.

GLGU. (2004). Grunderna för läroplanen för den grundläggande utbildningen. Helsingfors: Utbildningsstyrelsen.

Harrison, C., Hofstein, A., Eylon, B-S. \& Simon, S. (2008). Evidence-Based Professional Development of Science Teachers in Two Countries. International Journal of Science Education, 30 (5), 577-591.

Helldén G., Jonsson G., Karlefors I. \& Vikström A. (2010). Vägar till naturvetenskapens värld ämneskunskap i didaktisk belysning. Stockholm, Liber.

Jeronen, E., Niemitalo, H., Jeronen, J. \& Korkeamäki, R-L. (2010). Conceptions of Finnish 7-8 years old pupils on human anatomy and physiology - A phenomenographic case study. I G. Çakmakci \& M. F. Taşar (Red.). Contemporary science education research: Learning and assessment (s. 145-149). A collection of papers presented at ESERA 2009 Conference, ESERA 2010. Tillgänglig 2010-08-12: http://www.naturfagsenteret.no/esera/Book4.pdf.

Komparativt studium af de nordiske læreruddannelser. (2009). TemaNord 2009:505. Nordisk Ministerråd, København.

Kärrqvist, C. \& Frändberg, B. (2008). Vad händer i NO-undervisningen? En kunskapsöversikt om undervisningen i naturorienterande ämnen i svensk grundskola 1992-2008. Stockholm: Skolverket. Tillgänglig 2010-04-27: http://www.skolverket.se/publikationer?id=2121.

Lundin, M. (2007). Students' participation in the realization of school science activities. Nationella forskarskolan i naturvetenskapernas och teknikens didaktik, FontD, Institutionen för samhälls- och välfärdsstudier, Linköping University, Norrköping.

Nyström, N. (2007). TIMSS fixpunkter. En analys av vad elever med olika resultat $i$ TIMSS 2003 vet och kan göra. Tillgänglig: http://www8.umu.se/edmeas/publikationer/pdf/BVM $\% 20$ nr\%2020\%20ny.pdf.

Osborne, J., Simon, S. \& Collins, S. (2003). Attitudes towards science: a review of the literature and its implications. International Journal of Science Education, 25 (9), 1049-1079.

Óskarsdóttir, G. (2006). Childrens ideas about the human body and how they change during two school years. I L. Bering, J. Dolin, L. B. Krogh, J. Sølberg, H. Sørensen \& R. Troelsen (Red.) Naturfagsdidaktikkens mange facetter (s. 237-245). København: Danmarks Pædagogiske Universitet.

Palmberg, I. (2008). Hållbar utveckling och klimatförändringen i skolan och lärarutbildningen pedagogiska implikationer på basen av tidigare forskning. I I. Palmberg \& E. Jeronen (Red.) Harmoni eller konflikt? Forskning om miljömedvetenhet $i$ skolan och lärarutbildningen, (Rapport Nr. 24, 61-85). Åbo Akademi, Pedagogiska fakulteten. 
Palmberg, I., Jeronen, E. \& Yli-Panula, E. (2008). Luokanopettajaksi opiskelevien tiedot ja käsitykset biologian, maantieteen ja terveystiedon perustiedoista opiskelun alkuvaiheessa. (Klasslärarstuderandes kunskaper i och uppfattningar av vad som är baskunskap i biologi, geografi och hälsokunskap i början av studierna) I A. Kallioniemi (Red.) Uudistuva ja kehittyvä ainedidaktiikka. Ainedidaktinen symposiumi 8.2.2008 Helsingissä, (Tutkimuksia, 298, osa 1, s. 51-64). Helsingin yliopiston.

Palmberg, I. \& Svens, M. (2010). Klasslärarstuderandes intresse för och kunskaper i biologi och hållbar utveckling. (Manuskript godkänt till Helsingfors universitets forskningsserie)

Pojaghi, B. (1996). How children of 9-11 years describe the inside of the body and its functioning. A starting point for the biology teaching syllabus. I M. O. Valente, A. Bárrios, A. Gaspar, \& V. D. Teodoro (Red.) Teacher training and values education. (sidetall?) Selected papers from the $18^{\text {th }}$ Annual Conference of the ATEE, Lisboa.

Prokop, P. \& Fančovičová, J. (2006). Students' ideas about the human body: Do they really draw what they know? Journal of Baltic Science Education, 2 (10), 86-95.

Prokop, P. \& Fančovičová, J. \& Tunnicliffe, S.D. (2009). The effect of instruction on expression of children's knowledge: How do children see the endocrine and urinary system? International Journal of Environmental \& Science Education, 4 (1), 75-93.

Reiss, M.J. \& Tunnicliffe, S.D. (2001). Students' understandings of human organs and organ systems. Research in Science Education, 31, 383-399.

Reiss, M.J., Tunnicliffe, S.D., Møller Andersen, A., Bartoszeck, A., Carvalho, G.S., Chen, S-Y., Jarman, R., Jónsson, S., Manokore, V., Marchenko, N., Mulemwa, J., Novikova, T., Otuka, J. Teppa, S. \& Van Rooy, W. (2002). An international study of young peoples' drawings of what is inside themselves. Journal of Biological Education, 36 (2), 58-64.

Rice, D. (2005). I didn't know oxygen could boil! What preservice and inservice elementary teachers answers to 'simple' science questions reveals about their subject matter knowledge. International Journal of Science Education, 27 (9), 1059-1082.

Sanders, M. (1993). Erroneous ideas about respiration: the teacher factor. Journal of Research in Science Teaching, 30 (8), 919-934.

Schiefele, U., Krapp, A. \& Winteler, A. (1992). Interest as a predictor of academic achievment: A meta-analysis of research. I K.A. Renninger, S. Hidi \& A. Krapp (Red.) The role of interest in learning and development (sidetall?) Hillsdale, NJ: Lawrence Erlbaum Assosiates, Publishers.

SFS. (2007). Förordning om ändring $i$ högskoleförordningen (1993:100). Bilaga 2 Examensordning. Gäller från den 1 maj 2007. Examensordning för lärarutbildningen. Högskoleverket 2007: 129.

Sinatra, G.M. \& Pintrich, P. R. (2003). The role of intensions in conceptual change learning. I G. M. Sinatra \& P. R. Pintrich (Red.) Intentional conceptual change (s. 1-18). Lawrence Erlbaum Associates.

Sjøberg, S. \& Schreiner, C. (2006). Elevenes forhold til naturfag og teknologi: Et Nordisk og internasjonalt perspektiv basert på ROSE-prosjektet. I L. Bering, J. Dolin, L. B. Krogh, J. Sølberg, H. Sørensen \& R. Troelsen (Red.). Naturfagsdidaktikkens mange facetter (s. 65-83). København: Danmarks Pædagogiske Universitet.

Skolverket. (2000). Grundskolans kursplaner och betygskriterier. Västerås: Skolverket och Fritzes.

Skolverket. (2006a). LPF94 - Läroplan för de frivilliga skolformerna (gymnasieskolan). Kursplan för BI 1202-Biologi B. Tillgänglig 2010-04-24: http://www.skolverket.se/sb/d/726/a/13845/ func/kursplan/id/2910/titleID/BI1202\%20-\%. Kursplan för NK 1202- Naturkunskap B. Tillgänglig 2010-04-24: http://www3.skolverket.se/ki03/front.aspx?sprak=SV\&ar=0304\&infoty $\mathrm{p}=5$ \&skolform $=21 \& \mathrm{id}=3278$ \& extraId.

Skolverket. (2006b). LPO94 - Läroplan för det obligatoriska skolväsendet, förskoleklassen och fritidshemmet. Tillgänglig 2010-04-24: http://www.skolverket.se/sb/d/468.

Skolverket. (2009). Skolverkets bild av utvecklingen av kunskapsresultaten i grundskolan och av elevers studiemiljö - redovisning av uppdrag att utarbeta ett sammanfattande underlag avseende utvecklingen av kunskapsresultaten i grundskolan. PM 2009-01-29; Dnr 2008:3010. Tillgänglig 2009-02-03: http://www.skolverket.se/publikationer?id=2154. 
SOU. (2007). Tydliga mål och kunskapskrav i grundskolan - Förslag till nytt mål- och uppföljningssystem. Statens offentliga utredningar. Utbildningsdepartementet 2007: 28. Tillgänglig 2010-04-24: http://www.sweden.gov.se/sb/d/8439/a/81428.

SOU. (2009). Bäst $i$ klassen - en ny lärarutbildning. Utbildningsdepartementet 2009/10: 89.

Teixeira, F.M. (2000). What happens to the food we eat? Children's conceptions of the structure and function of the digestive system. International Journal of Science Education, 22(5), 507520.

Tunnicliffe, S.D. (2004). Where does the drink go? Primary Science Review, 85 (Nov-Dec), 8-10. Undervisningsministeriet (2008). Gymnasium, DK, oplysningsark. Tillgänglig 2010-04-24: http:// www.uvm.dk/ /media/Files/Udd/Gym/PDF08/Fakta/080201_faktaark_stx.ashx.

Utbildningsstyrelsen (2009). LUMA - Suomen menestystekijä nyt ja tulevaisuudessa. Matematiikan ja luonnontieteiden neuvottelukunnan muistio. (LUMA - Finlands framgångsfaktor nu och i framtiden). Promemoria/Betänkande av kommissionen i matematik och naturvetenskaper.

Vejledning (2008) Biologi C. Undervisningsministeriet. Tillgänglig 2009-10-09: http://www.uvm. dk/ /media/Files/Udd/Gym/PDF08/Vejledninger/stx/080701_biologi_C_stx_vejledning. ashx.

Vikström, A. (2005). Ett frö för lärande - En variationsteoretisk studie av undervisning och lärande $i$ grundskolans biologi. Luleå tekniska universitet. Institutionen för utbildningsvetenskap 2005: 14.

Yip, Y.D. (1998). Teachers' misconceptions of circulatory system. Journal of Biological Education, 32, 207-216.

Yli-Panula, E. (2005). Tutkivaan oppimiseen ja ongelmanratkaisuun perustuvat työtavat (Undesökande och problembaserade arbetsmetoder). I V. Eloranta, E. Jeronen \& I. Palmberg (Red.). Biologia eläväksi - biologian didaktiikka (Levande biologi - biologins didaktik) (s. 97-110). Jyväskylä: PS-Kustannus.

Åström, M. (2007). Integrated and subject-specific. An empirical exploration of science education in Swedish compulsory schools. Norrköping: The Swedish National Graduate School in Science and Technology Education, FontD. Linköping University, Department of Social and Welfare Studies. 